\title{
ACRL Midwinter meetings in Philadelphia
}

\section{A brief overview}

\section{Board of Directors}

Board of Directors Meeting I: Friday, January 24, 2020, 1:00-4:00 p.m.

Board of Directors Meeting II (Part 1 of 2): Saturday, January 25, 2020, 11:00 a.m.-12:00 p.m.

Board of Directors Meeting II (Part 2 of 2): Saturday, January 25, 2020, 3:30-5:30 p.m.*

*Guests are invited to address the Board during the open mic period from 5:00-5:30 p.m., those who wish to speak should arrive by 5:00 p.m.

\section{Forums}

Student Learning and Information Literacy Committee Forum: Saturday, January 25, 2020, 10:30-11:30 a.m. A forum for timely issues in student learning and information literacy with the ACRL Student Learning and Information Literacy Committee.

ACRL/SPARC Scholarly Communication Forum: Saturday, January 25, 2020, 3:00-4:00 p.m. Through its standing Research and Scholarly Environment Committee, ACRL sponsors a regular forum at both the ALA Midwinter Meeting and Annual Conference to broaden the base of librarians who are knowledgeable about and engaged in scholarly communication issues. The highly popular forum series is cosponsored by the Scholarly Publishing and Academic Resources Coalition. The topic and speakers are chosen 60 to 90 days before the conference based on issues that are most relevant at that time.
Information Literacy Framework Professional Development: Sunday, January 26, 2020, 9:00-10:00 a.m. Professional development for working with the Framework for Information Literacy for Higher Education with the ACRL Student Learning and Information Literacy Committee.

\section{ACRL special events at 2020 ALA Midwinter Meeting}

Friday, January 24

European Studies Section. Social, Time: TBD. Location: TBD. Contacts: Joanneke Elliott, joanneke@email.unc.edu.

Science and Technology Section. Social, 6:30-8:30 p.m., pre-registration required. Contact: Sam Putnam, sputnam@ufl.edu and Sarah Jeong, jeongsh@wfu.edu.

\section{Saturday, January 25}

Rare Books \& Manuscript Section. Social, 6:30-8:00 p.m. Location: City Tap, 2 Logan Square, Philadelphia, Pennsylvania. Contact: Diane Dias De Fazio, diane-defazio@uiowa. edu. No registration required.

Science and Technology Section. Dinner, 6:30-8:30 p.m. Contact: Sam Putnam, sputnam@ufl.edu and Sarah Jeong, jeongsh@wfu. edu. Pre-registration required.

Sunday, January 26

Digital Scholarship Section. Social, 6:008:00 p.m. Location: TBD. Contact: Marguerite Helen Albro, mdunn3@clemson.edu. z

(continues on page 637) 
Kim Olson-Charles has been named head of library public services at the W. A. Budden Library at the University of Western States.

Bridget Rowan Wipf has been appointed librarian for the College of Engineering, Informatics, and Applied Sciences with the Teaching, Learning, and Research Services Department at Northern Arizona University's Cline Library.

\section{Retirements}

Jeanne Drewes has retired as chief of the binding and collections care division of the preservation directorate at the Library of Congress.

Harold M. Leich has retired from the European Division of the Library of Congress, where he had served as Russian area specialist librarian since 1987. He previously worked at the University of Illinois-Urbana's Slavic/East European Library from 1969 to 1987.

\section{Cheryl Middleton,} associate university librarian at Oregon State University (OSU), is retiring in January 2020 after 34 years at the university. Middleton served as ACRL president (2017-18). While president, she worked

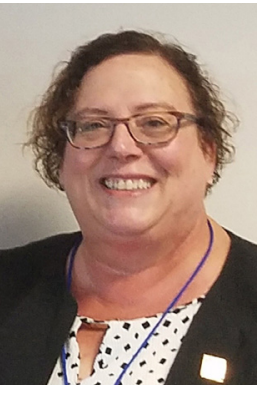

Cheryl Middleton with the ACRL Board and membership to take a stand and issue statements against the erosion of social justice and for equity, diversity, and inclusion. Middleton joined OSU Libraries and Press in 1983. She left OSU in 1993 to obtain her MLS. In 1998, she returned to OSU as life sciences librarian. She received tenure in 2002, and since then has been in a number of positions at OSU Libraries: department head for access and undergraduate instruction; associate university librarian for teaching and engagement; and, her most recent role, the associate university librarian for research and scholarly communication. $\boldsymbol{n}$

("ACRL Midwinter meetings in Philadelphia," cont. from page 632)

\section{ACRL Discussion Groups in Philadelphia}

Assessment: Saturday, January 25, 3:00 -4:00 p.m. Topic: Assessment that Makes a Difference. Join colleagues to discuss best practices and challenges in the practice of assessment.

Balancing Baby and Book: Sunday, January 26, 4:00-5:00 p.m. Topic: How parenting and librarianship can be successfully intertwined.

Copyright: Saturday, January 25, 10:3011:30 a.m. Topic: Legislative, judicial, and regulatory developments related to copyright and libraries in higher education.

Heads of Public Service: Saturday,January 25,4:00-5:00 p.m. Topics: Promoting traditional library services in an innovative way, and using self-service technology in public services beyond book checkout (e.g., laptop kiosks, scanning stations, charging lockers).

Leadership Discussion Group: Saturday, January 25, 4:00-5:00 p.m. Topic: From Support Staff to Librarians: A Discussion on CareerTransitions.

MLA International Bibliography in Academic Libraries Discussion Group: Saturday, January 25, 3:00-4:00 p.m.

Personnel Administrators and Staff Development: Saturday, January 25, 10:3011:30 a.m. and Sunday,January 26,9:00-10:00 a.m. Topic: Emerging trends and best practices for human resource management and organizational development in academic libraries.

Scholarly Communication: Sunday, January 26, 2:30-3:30 p.m. Topic: Follow up on the ACRL/SPARC Forum. 